\title{
Hungarian Constitutional Court: Transparency and Business Activities of the State ${ }^{1}$
}

\author{
Judgments of 31 March 2016, Decisions of 7/2016 (IV 6) and 8/2016 (IV 6) \\ Emese Szilágyi
}

\begin{abstract}
The Constitutional Court of Hungary recently delivered two important decisions concerning freedom of information. In both cases, the National Assembly attempted to curtail the transparency of the Central Bank and the Hungarian Mail, and the President of the Republic requested for an ex ante constitutional review. The decisions contain pivotal arguments concerning legal certainty and freedom of information, and can be read as proof that in the most crucial cases the Constitutional Court of Hungary still stands up against the majority of the parliament.

However, it is worth mentioning that in the more straightforward case - the decision about the modification of the Act on the Central Bank of Hungary - there was a wide professional consensus on the unconstitutionality of the new rules. This consensus was supported by the opinion of the National Authority for Data Protection and Freedom of Information. The reasoning of the other decision which examines the new rules of the Postal Service Act could arguably be read two different ways, as will also be elaborated in this paper.
\end{abstract}

\section{Preliminary Remarks}

The National Assembly of Hungary on 1 March 2016 approved amendments to the Act on the Central Bank of Hungary ${ }^{2}$ (hereinafter: MNBtv) and to the Postal Service Act. ${ }^{3}$ These amendments intended to limit the availability of public data ${ }^{4}$ related to the operations of the Central Bank of Hungary (hereinafter: MNB) and the Hungarian Mail. The modifications fit into the range of those attempts, with which the legislator tried to limit the transparency of the state. Most infamous was the modification ${ }^{5}$ enacted during the summer of 2015: the new provisions allow state organs to charge those requesting public information in order to complete the information request, as well as doubling the deadline for response. Up to this point, a person requesting data of public interest had to pay only photocopying fees, but after the enactment of the provisions the interested citizens have to pay the complete cost of the release of the documents.

The new amendments enacted in March 2016 also tried to diminish the transparency of the state. The provisions, which aimed to classify the spending of the Central Bank happened after a journalist sued to gain access to details of the spending by the MNB's Pallas Athene Domus Animae Foundation. The Foundation was established in order to support the training of experts in economics, finance, and above all in banking and spread 'unorthodox economics' methods, as opposed to the 'obsolete doctrines and mistakes of the neoliberal economics school. ${ }^{16}$

The Hungarian Mail was also sued successfully by watchdog organisations in order to publish detailed information about contracts with certain media companies, which were widely known as owned by government-

\footnotetext{
${ }^{1}$ The author thanks Federica Cristani and Tamás Hoffmann for their helpful remarks on earlier versions of the present paper.

Act CCVIII of 2011 on the Central Bank of Hungary.

${ }^{3}$ Act CLIX of 2012 on the Postal Services.

${ }^{4}$ In the Hungarian legal regime there are two different forms of publicly available data, namely 'data of public interest' and 'data public on grounds of public interest'. As in connection with the arguments used in these cases the difference between them has no importance, in this article I will refer to both as public or publicly available data.

5 Act CXXIX of 2015.

${ }^{6}$ The Central Bank spent HUF 200 billion for this aim in 2014. In comparison, the annual state budget for higher education in that year was HUF 136.7 billion.
} 


\section{ICL Journal @ Verlag Österreich}

friendly businessmen. The contracts contained the favourable conditions of distributing some local newspapers, which were freely available for citizens. More recently the questionable activity of the real estate fund owned by the Hungarian Mail and its fund manager company (Magyar Posta Takarék) got into the focus of public attention.

Both the lower courts and the supreme court of Hungary - now re-named as Curia of Hungary ${ }^{7}$ - consistently argued that organizations that use public funds must disclose how the public money has been spent and must account for their use. The courts reasoned that however the foundations and other satellite-organizations of state outlets can be considered as separate legal entities, this does not mean that the money managed by them lose its public status. It is safe to say that with the modifications at stake the legislator aimed to change this judicial practice.

\section{The Decision on the Modification of the Act on the Central Bank}

\section{A. Facts of the Case}

\section{The Amendments of the Law on the Central Bank}

The National Assembly of Hungary on 1 March 2016 approved amendments to the Act on the Central Bank of Hungary. However, the bill ${ }^{8}$ did not contain any kind of reasoning to explain the ultimate aim of the legislator, the amendment intended to limit the availability of public data related to the operations of the Central Bank of Hungary. More precisely the bill tried to restrict access to public information about business associations and foundations established by the Central Bank of Hungary.

In order to achieve this, the new Section 162 para 7 of the MNBtv declared that concerning the foundations established by the Central Bank only certain minimal information - which is closely related to the establishment itself, such as the letter of intent - is required to be disclosed, otherwise any further data controlled by the foundation can be accessed only under the conditions prescribed by the act on the freedom of association, on public purpose status, and the operation of civic organizations ${ }^{9}$ (also known as Civic Act). Another provision, namely a new Section 162 para 4 of the MNBtv, declared that data controlled by business associations of the Central Bank can be disclosed only under the more rigorous conditions prescribed by Section 137 para 2 of the MNBtv. This provision originally applied only to data generated or recorded in the course of proceedings for the adoption of certain decisions - such as decisions of the Monetary Council or Financial Stability Council and the executive board -, in which cases publicity is restricted in order to ensure the objectivity and effectiveness of the decision-making process. In earlier landmark decisions the Constitutional Court had pointed out that restricting the openness of the data generated during a decision-making process about controversial public policyissues may be proven necessary in order to ensure the objectivity of the civil service by liberating them from the pressure of the public opinion. ${ }^{10}$

In sum, these new provisions would have been able to narrow the extent of publicly available data regarding to the activity and operations of the Central Bank and its various satellite organizations. In addition, the new provisions should have been applied a) in cases where the request for public data had been presented even before the new rules entered into force; and b) regarding to data, which were compiled or recorded before the modifications were enacted.

\footnotetext{
${ }^{7}$ Under Act CLXI of 2011 on the Organization and Administration of Courts, the Supreme Court of Hungary has been renamed for the archaic-sounding Curia.

${ }^{8}$ Bill T/9380 http://www.parlament.hu/irom40/09380/09380.pdf [accessed 28.5.2016].

${ }^{9}$ Act CLXXV of 2011 on the freedom of association, on public purpose status, and the operation of civic organizations.

${ }^{10}$ Decisions 34/1994 (VI 24) and 12/2004 (IV 7) of the Constitutional Court.
} 


\section{ICL Journal @ Verlag Österreich}

\section{The Petition of the President}

The President of the Republic, Mr János Áder, considered that the above-described new norms were in conflict with the Fundamental Law, thus before promulgation he requested an ex ante constitutional review. In such cases the Court examines the conformity with the Fundamental Law of the provisions of the adopted but not yet promulgated Act referred to in the petition. ${ }^{11}$

In his petition the President pointed out that both the foundations and business associations established by the MNB managed public funds and according to Article 39 para 2 of the Fundamental Law 'every organisation managing public funds shall be obliged to publicly account for its management of public funds. Public funds and national assets shall be managed according to the principles of transparency and the purity of public life. Data relating to public funds and national assets shall be data of public interest. ${ }^{12}$

The President argued that this infringement of the freedom of information was not in conformity with the requirements of Article I para 3 of the Fundamental Law either, because the modified act did not indicate that the aim of the restriction was to protect another fundamental right or constitutional value.

In addition, the President stated that the Act contradicted the constitutional requirement of legal certainty and therefore the principle of rule of law, too, because its provisions - if promulgated and entered into force should have been applied retrospectively.

\section{Relevant Provisions of the Fundamental Law}

\section{Article B}

(1) Hungary shall be an independent, democratic state governed by the rule of law.

Article I

(3) The rules for fundamental rights and obligations shall be laid down in an Act. A fundamental right may only be restricted to allow the effective use of another fundamental right or to protect a constitutional value, to the extent absolutely necessary, proportionate to the objective pursued and with full respect for the essential content of such fundamental right

Article VI

(2) Everyone shall have the right to the protection of his or her personal data, as well as to access and disseminate data of public interest.

Article 39

(2) Every organisation managing public funds shall be obliged to publicly account for its management of public funds. Public funds and national assets shall be managed according to the principles of transparency and the purity of public life. Data relating to public funds and national assets shall be data of public interest.

\section{B. The Ruling of the Constitutional Court}

\section{The Reasoning on Freedom of Information}

\footnotetext{
${ }^{11}$ See also: Sections 23 and 23/A of Act CLI of 2011 on the Constitutional Court.

${ }^{12}$ In this paper I will use the official translation of Fundamental Law, released by the Government of Hungary. http://www.kormany.hu/download/e/02/00000/The\%20New\%20Fundamental\%20Law\%20of\%20Hungary.pdf [accessed 28.5.2016].
} 


\section{ICL Journal @ Verlag Österreich}

The most important questions according to the Constitutional Court are the following: a) should the data controlled by the foundations and commercial associations be considered as data of public interest; b) in case the answer is yes, do the provisions at stake infringe the right of freedom of information; and finally c) can the infringement be considered as constitutional?

The Court recalled that the Central Bank is an independent constitutional outlet, which is not a competitor in the private market. The Court also pointed out that according to Section 162 para 2 of the MNBtv, 'in line with its tasks and primary objective, the MNB may establish a business association in which it has a majority holding or may create a foundation. ${ }^{13}$ In cases when the MNB establishes foundations or business corporations, the source of the assets offered by the MNB is necessarily public fund. It is, however, questionable whether the separation of the foundation or company after the establishment-process has in itself a direct effect on the publicity of its management of funds. The judges also concluded that because the Central Bank itself is a property of the state, its shares and assets in its own foundations and business associations must be considered as indirect properties of the state and as such, they must be regarded as national assets. This means - according to the Court - that companies dominantly controlled by institutions which perform public tasks must be considered as bodies performing public tasks and managing public funds themselves, too, therefore irrespectively to their independency, access to the data controlled by them must be ensured. Concerning the foundations of the MNB, the Court underlined that they also must perform public tasks; and added that if the foundations which managed exclusively public funds had not carried out public duties, their establishment in itself would have contradicted to Section 162 para 2 of the MNBtv. The fact that these foundations manage public funds is not in any way affected by their independency.

Thus, the answer to the first question - namely, whether the data, controlled by the foundations and companies, should be considered as data of public interest - is a definite yes, based on the fact that these companies manage public funds and the foundations perform public tasks - concluded the judges.

Turning to the second question, whether the challenged provisions infringe the freedom of information, the Court underlined that the provisions require Section 137 para 2 of the MNBtv to be applied for data controlled by commercial companies, which are owned by the MNB. The law prescribes that 'data generated or recorded in the course of proceedings for the adoption of the decision of the Monetary Council, the Financial Stability Council and the executive board and data used to support decisions relating to the performance of basic tasks shall not be publicly available for thirty years from their generation, during which time no request for access to data supporting decisions shall be submitted either before or after the adoption of the decision. ${ }^{14}$ As the Court points out, the original provision applies only for data which were 'generated or recorded in the course of proceedings for the adoption of the decision' - so-called preparatory data -, while due to the modification the secrecy would apply to any kind of data, independently of its nature. According to the Court, the aim of this provision is not clear and the underlying reasons and arguments, which justify the constitutionality of the original rule may not be enough to support the necessity of the modification.

According to the new provisions, the rules of the Civic Act should be applied for data controlled by the foundations of the MNB. This rule would substantially limit the availability of public data. The Court underlines that the new provisions rule out the possibility to apply the general rules of the Act CXII of 2011 on the Right of Informational Self-Determination and on Freedom of Information ${ }^{15}$ (hereinafter: Infotv), even when the public nature of the data originates from the Fundamental Law itself.

The last question which the Court answered in order to fulfil the test is whether the infringement can be considered as constitutional or not. The judges underlined that the Court had interpreted the constitutional right of access to public data as freedom of information since the democratic transition of 1989 and this interpreta-

\footnotetext{
${ }^{13}$ In this paper I will use the official translation of the Act on the Central Bank, released by the Central Bank of Hungary; https://www.mnb.hu/letoltes/mnb-torveny-2016-05-06-en.pdf [accessed 28.5.2016].

${ }_{14}$ Article 137 para 2 of the MNBtv.

${ }^{15}$ Official translation, released by the National Authority for Data Protection and Freedom of Information: http://www.naih.hu/files/Act-CXII-of-2011_EN_16-Sept-2015.pdf [accessed 28.5.2016]
} 


\section{ICL Journal @ Verlag Österreich}

tion has been upheld also after the enactment of the new Fundamental Law. ${ }^{16}$ Since then, the principle of publicity applies to public data as a general rule.

In addition, the Court has upheld those principles, which were elaborated in its jurisprudence under the scope of the previous Constitution of the Republic of Hungary. ${ }^{17}$ Thus, it has highlighted that freedom of information has a crucial importance in guaranteeing the effectiveness of freedom of opinion and by that, the democratic operation of the state itself. Hence, freedom of information is a cornerstone of democracy, and a safeguard of rule of law. 'Without the continuous attention of the public the state may alienate from its citizens and its operations shall become unpredictable, unforeseeable and thus, explicitly dangerous; the lack of transparency poses an acute threat on civil rights and liberties.' - cited the Court the most important arguments of its landmark decision from $1994 .{ }^{18}$ The Court also emphasized that freedom of information helps to realize the National Avowal's statement: 'We hold that democracy is only possible where the State serves its citizens and administers their affairs in an equitable manner, without prejudice or abuse.' Therefore transparency and purity of public life are basic constitutional requirements, safeguards of the democratic operation of the state.

Finally, the Court cited the necessity-proportionality test from the Fundamental Law. According to Article I para 3 of the Fundamental Law, a 'fundamental right may only be restricted to allow the effective use of another fundamental right or to protect a constitutional value, to the extent absolutely necessary, proportionate to the objective pursued."' Hence, necessity includes two elements: the infringement must serve a constitutional goal and must be adequate. But as the exact goal of the legislator is not elaborated in the bill, the Court is not in the adequate position to examine the reasonableness of the new rules. The legislator neglected to justify the modifications, therefore fulfilling the constitutional 'balancing' procedure has become impossible.

According to the new Section 162 para 4 of the MNBtv, the public accessibility of the data would be dependent on the personality of the controller instead of the nature of the data, which means that if a data was controlled by the MNB, it would be publicly accessible, but if it was controlled by its own commercial association, it could not be disclosed. However, it is possible that restricting the publicity of some data controlled by these companies can be justified constitutionally, but the new provisions - as they are vague and too widely defined are in contradiction with the Fundamental Law of Hungary - concluded the Court.

\section{The Problem of Legal Certainty}

Based on its earlier case-law the Court highlighted that the prohibition on ex post facto law-making is not an absolute one, since the affected legal relations must differ from each other. Therefore, the Court must examine on a case by case basis whether in the actual case a detriment of legal certainty can be located. The Court examined two questions: a) whether the rule at stake is actually retrospective and b) whether it can be considered as detrimental.

The Court pointed out that the norm applies to procedures which had been started earlier and to data, which was generated before the Act has been enacted and promulgated. Therefore, the norms are clearly ex post facto. The Court also concluded that the right of access to public data first occurs when the data is generated, until it is not infringed by a constitutional act. Thus, the norms at stake interfere with a basic liberty retrospectively, hence contradict to Article B para 1 of the Fundamental Law.

\section{Dissenting opinions of Béla Pokol and András Varga Zs ${ }^{19}$}

\footnotetext{
${ }^{16}$ See for eg Decision 2/2014 (I 21) of the Constitutional Court.

${ }^{17}$ Act XX of 1949 The Constitution of the Republic of Hungary.

18 Decision 34/1994 (VI 24) of the Constitutional Court. Translation from the Author.

${ }^{19}$ In the practice of the Hungarian Constitutional Court, the possibility of writing and also publishing dissenting and concurring opinions is recognized since 1989. This can be considered as a part of following the example of the Bundesverfassungsgericht, which was the role model for the Hungarian Constitutional Court during the democratic transition. László Sólyom even calls the Constitutional Courts of the Post-Communist transition 'generation of the granddaughters of the German Constitutional Court'. László Sólyom, 'The Role of Constitutional Courts in the Transition to Democracy' in International Sociology (March 2003) 137.
} 


\section{ICL Journal @ Verlag Österreich}

Béla Pokol in his dissenting opinion argued that the Court should have had differentiated between the new rules regarding to commercial companies and foundations. In his opinion in order to ensure the conditions of fair competition on the economic market, the data controlled by these companies should have been declared as exceptions from the general rule of publicity.

Moreover, he did not agree with the Court's argumentation that in cases of retrospectivity the violation on the rule of law can only be decided on a case by case basis. Pokol argues that the Court rather should have set up a general rule. In his opinion the correct form for the problem would be that laws with retroactive power could apply also to current permanent legal relations, which had started in the past, before the law at stake entered into force, but regarding to rights and obligations which originate from these permanent legal relationships the law can only be applied only after entering into force.

In his dissenting opinion András Varga Zs highlights that the Constitutional Court is bound only by the Fundamental Law and not by any other law. This also means that regarding to freedom of information, not only one form of legal regime can be considered as constitutional, and a deviation from the general rules - namely in this case from the norms of the Infotv - is not necessarily against the Fundamental Law.

He also underlines - while referring to the origins of human rights in general - that freedom of information is not in a close and untearable relationship with the basic 'human nature' of the citizens, and he adds that this particular freedom does not originate from the pure fact that someone was born to be a human being; this is rather a 'political' freedom closely related to political liberties. He also argues that freedom of information has two phases: the first is the right to learn about the public data and the second is the publicness of the data. In his opinion a change in the second phase - that the particular data 'looses' its public nature - does not have any effect on the former, thus, on the core of the basic right.

Varga Zs also stated that the infringement regarding to data controlled by business companies which were founded by the MNB could be justified with the argument of protecting their position on the economic marketplace. He did not agree with the statement that the retrospective nature of the rules interfere with the principle of legal certainty and rule of law, either.

\section{The Decision about the Modified Rules of the Postal Service Act}

\section{A. Facts of the Case}

\section{The Amendments of the Law on Postal Services}

On the very same day, 1 March 2016, the National Assembly enacted another modification of an act ${ }^{20}$ (hereinafter Bill), namely a modification of the Postal Service Act. ${ }^{21}$ According to the amendment, the new Section 53 para 4 of the Postal Service Act (hereinafter: Postatv) declared that data, which are in connection with the business-activity of the universal postal service provider or with any commercial association managed directly or indirectly by the universal postal service provider could not be considered as public if its publicity would cause a disproportionate disadvantage for the postal service provider or for the affected commercial association under the terms and conditions described in the Act on the Prohibition of Unfair Trading Practices and Unfair Competition. ${ }^{22}$

According to the reasoning of the Bill, the ultimate aim of the legislator was to harmonize the Postal Service Act with the Infotv; and to concretize those cases when the publicity of the data regarding to national assets would lead to a disproportionate disadvantage in the competitive market.

Section 2 of the Bill ordered that this new provision shall be applied in cases where the request for disclosure already had been presented before the modification entered into force, and also in current proceedings; and in addition regarding to any postal service contract, which had been concluded before the modification was enacted.

\footnotetext{
${ }^{20}$ Bill T/8829. http://www.parlament.hu/irom40/08829/08829.pdf [accessed 28.5.2016].

${ }^{21}$ Act CLIX of 2012 on The Postal Services.

22 Act LVII of 1996 on the Prohibition of Unfair Trading Practices and Unfair Competition.
} 


\section{ICL Journal @ Verlag Österreich}

\section{The Petition of the President}

The President in this case too, requested for an ex ante review of conformity with the Fundamental Law before promulgation. In his petition he argued that according to the modifications, the possibility to access to public data would be limited. Moreover, Section 2 of the Bill orders to apply these restrictions ex post facto. These provisions - argued the President - were in contradiction with the constitutional principles of legal certainty and rule of law, prescribed by Section B para 1 of the Fundamental Law.

\section{Relevant Provisions of the Fundamental Law}

\section{Article B}

(1) Hungary shall be an independent, democratic state governed by the rule of law.

\section{B. The Ruling of the Constitutional Court}

\section{The Argumentation of the Majority}

In their reasoning the judges pointed out that however the President asked only for the examination of Section 2 of the Bill, without examining Section 1 of the same Bill - or with other words the new Section 53 para 4 of the Postatv - the constitutionality of the challenged provision cannot be decided.

The Court underlined that according to the reasoning of the Bill, its aim is to enforce Article M para 2 of the Fundamental Law, which ensures fair economic competition. ${ }^{23}$ The Court also relied on the opinion ${ }^{24}$ of the $\mathrm{Na-}$ tional Authority for Data Protection and Freedom of Information. The Authority in this document ${ }^{25}$ stated that the final version of the Bill was in conformity with the other relevant legal provisions.

Regarding to the principle of legal certainty the Court highlighted that the prohibition of ex post facto lawmaking is not unconditional and is normative only in cases when the application of the challenged provision is disadvantageous for those affected by it. Therefore, the Court must decide on a case by case basis whether a particular rule interferes with the principle of legal certainty. The judges reminded that in Decision 10/2014 (IV 4) of the Constitutional Court it had already been argued that the legislator could use the tool of retroactive law-making if it constituted or broadened the scope of a right, or abolished the existing limitation of a right. Therefore, first of all, the Court had to examine whether the new provision regarding to the changes in the publicity of data controlled by the postal service provider or its business association infringed the freedom of information or not.

In order to answer this question, the Court compared the new Section 53 para 4 of the Postatv with the relevant provisions of the Infotv, especially with the definition of 'data of public interest ${ }^{26}$ and with the regulations on business secret. According to the regulation on business secret, publicity of data - especially of protected knowledge, such as 'know-how' - shall not have the effect of causing disproportionate difficulty in managing the business activity of the controller of the data, however this norm shall not prevent the accessibility of public data.

\footnotetext{
${ }^{23}$ Article M (2) of the Fundamental Law of Hungary: 'Hungary shall ensure the conditions of fair economic competition. Hungary shall act against any abuse of a dominant position, and shall protect the rights of consumers'. ${ }^{24}$ In this case the Authority issued an opinion about the Bill ex officio, under the conditions of Section 38 para 4 lit c) of the Infotv. The Constitutional Court has the possibility to ask for or rely on the relevant opinion of the affected authority, based on Section 57 para 2 of the Act CLI of 2011 on the Constitutional Court.

${ }^{25} \mathrm{NAIH} / 2016 / 1288 / 8 / \mathrm{J}$ http://www.naih.hu/files/NAIH_1288_8_2016_J.pdf [accessed 29.5.2016].

${ }^{26}$ Under Section 3.5 of the Infotv 'data of public interest' shall mean information or data other than personal data, registered in any mode or form, controlled by the body or individual performing state or local government responsibilities, as well as other public tasks defined by legislation, concerning their activities or generated in the course of performing their public tasks, irrespective of the method or format in which it is recorded, its single or collective nature; in particular data concerning the scope of authority, competence, organisational structure, professional activities and the evaluation of such activities covering various aspects thereof, the type of data held and the regulations governing operations, as well as data concerning financial management and concluded contracts.
} 


\section{ICL Journal @ Verlag Österreich}

Finally, the Court concluded that the particular provision at stake merely specified the already existing rules of the Infotv, and ensured the accessibility of public data. In addition, under the new provisions limiting the publicity of data is possible only to an extent which has already been enabled by the Infotv. as well. The Bill only refines the Postatv. in harmony with the relevant provisions of the Infotv - argued the judges - and instead of limiting, in fact rather broadens the possibility to access to public data, therefore strengthens the constitutional requirement of legal certainty. Thus, disadvantageous ex post facto law-making could not be found, according to the judges.

\section{The three Dissenting Opinions}

Ágnes Czine in her thoughtful dissenting opinion emphasized the relevant practice of the ordinary courts. She agreed with the majority, that an act interferes with the principle of legal certainty if it retrospectively declares unlawful an activity or narrows the scope of rights.

She cited landmark decisions of the Curia of Hungary. According to the Curia, from the aggregate interpretation of the relevant norms of the Infotv. and the Civil Code ${ }^{27}$ it can be derived that information regarding to the use of public funds cannot be considered as business secret. However, those cases, when access to some kind of particular data (such as publicity of particular technological processes and solutions, manufacturing procedures, logistical methods, or any other forms of know-how) would cause disproportionate disadvantage regarding to business-activity, can be considered as exceptions from the general rule. But the denial of disclosure cannot prevent the accessibility of public data. ${ }^{28}$ In cases when the controller of the data denies the disclosure, he must prove the lawfulness of his action, and its reasons. ${ }^{29}$ The Curia also pointed out that the legal basis for denial must be interpreted in the narrowest possible sense and denial is allowed only in cases where the public interest for the secrecy is more cumbersome than the public interest which supports the publicity of the particular data. In sum, Áges Czine concluded that the controller of the data is required to prove the reasons of the denial as it is not enough to simply rely on the legal provisions about business secrets. This practice of the courts realizes an earlier decision of the Constitutional Court, according to which publicity is the general rule and any limit on the publicity must be considered exceptional. ${ }^{30}$

According to Czine, the new Section 53 para 4 of the Postatv contradicts to the already existing practice of the courts as it was demonstrated above, because the case-law requires a more specific justification for denial. Under the new provisions business secret may become a more cumbersome limit on freedom of information. If the real aim of the legislator would be to create harmony with the Infotv., the new provisions should not have been applied to pending cases, because the rules of the Infotv. were authoritative even without any modification on the Postatv. However, according to the legislator the current norms put a disproportionate burden on the controller, which induces that the real aim is to narrow the accessibility of the public data.

Ágnes Czine also emphasized that under Article 24 (4) of the Fundamental Law ${ }^{31}$ the Court would have had the right to examine the constitutionality of these rules, as well. She added that the new provisions weaken the guarantees of freedom of information with introducing such unclear categories, as disproportionate advantage, which now can be a basis for denial. Also, the new provisions narrow the freedom for interpretation of the courts. However, according to principles elaborated earlier by the Constitutional Court, the legislator is obliged to enact legal regulations which are reliable safeguards of freedom of information. Thus, the provisions at stake retrospectively interfere with the freedom of information, which contradicts to the principle of legal certainty, as well.

\footnotetext{
${ }^{27}$ Act $\mathrm{V}$ of 2013 on the Civil Code.

${ }^{28}$ Decision Pfv.IV.21.454/2013/3 of the Curia of Hungary.

29 Decision Pfv.IV.21.535/2015/6 of the Curia of Hungary.

${ }^{30}$ Decision 12/2004 (IV 7) of the Constitutional Court

${ }^{31}$ Article 24 para 4 of the Fundamental Law of Hungary: 'The Constitutional Court may review and/or annul any provision not requested to be reviewed of a legal regulation only if there is a close substantive connection between that provision and the provision requested to be reviewed of the legal regulation.'
} 


\section{ICL Journal (C) Verlag Österreich}

In his dissenting opinion Béla Pokol also concluded that Section 2 of the Bill interferes with the prohibition of ex post facto law-making, hence its unconstitutionality should have been declared by the majority opinion. He stressed that the approach of the Court towards the problem - namely the acceptance of case by case analysis - endangers the legitimacy of the Constitutional Court, because the decisions are not foreseeable.

In the concrete case the problem at stake does not only apply to a legal relation, which originates in the past, but to a right which has already been exercised in the past, and is currently under reconsideration by courts. However, in cases of contracts which concluded in the past, but requests for data has not been presented yet, the new provision can be applied, according to Pokol.

Péter Szalay also concluded that the Court should have declared Section 2 of the Bill unconstitutional, on the basis that it interferes with the prohibition of retrospective law-making. He underlined that the President's petition did not state the unconstitutionality of the new Section 53 para 4 of the Postatv, but disapproved Section 2 of the Bill. In Szalay's opinion the Court instead of examining the unconstitutionality of the provisions, especially said Section 53 para 4, merely interpreted the relevant legal norms. However, even this interpretation should have led to the declaration of unconstitutionality. Because one core element of the prohibition of retrospective law-making is that the legislator cannot intervene in pending cases in the courts - as it happened in the current case. Therefore, Section 2 of the Bill interferes with the principle of legal certainty and is in contradiction with the Fundamental Law.

\section{Assessment}

The two decisions further elaborate the rule of thumb in the Constitutional Court's newer case-law regarding to the problem of retrospective law-making. In both cases the Court underlined that retrospective law-making interferes with the principle of legal certainty when it causes disadvantage to the citizens. However, the judges also pointed out that this prohibition is not absolute: retrospective law-making is possible when the law constitutes or broadens the scope of a right, or abolishes the existing limitation of a right. The constitutional test, which the Court used in these two decisions, consists of two steps: first, it must be decided whether the challenged provision is in fact retrospective; and secondly, the judges examine whether it terminates or limits an already existing right.

However, according to an earlier, more rigorous argument of the Constitutional Court (which was based on the previous Constitution of Hungary) a norm which in itself - based on its content - would not be considered as unconstitutional, may still interfere with the principle of legal certainty if it negatively influences the legal position of those affected by it. In this concrete case the interference in itself, without any additional harm on citizens' rights, creates enough ground to establish the unconstitutionality of the norm. ${ }^{32}$ Thus, so far as the Court does not change its position expressly, we must presume that an infringement of a basic right or liberty is not a necessary pre-condition in the Court's practice to declare the interference with the prohibition of ex post facto law-making.

However, it is worth mentioning, that since the Fundamental Law had entered into force, the Court many times declared that regulations, which applied to long-term legal relations and curtailed the rights or made the legal positions of those affected by it more cumbersome, were in accordance with the new constitution of Hungary. ${ }^{33}$ This means a considerable deviation from the earlier practice of the Court, however a clear and explicit test has not been established, yet. As Béla Pokol points out in his dissenting opinions repeatedly, this approach creates uncertainty.

As for freedom of information, the picture is somewhat opaque. The decision on the foundations and business associations of the MNB cannot be considered as a surprise: the conclusion which the Court drew, directly

\footnotetext{
${ }^{32}$ Decision 64/2002 (XII 3) of the Constitutional Court.

${ }^{33}$ See Béla Pokol's concurring opinion attached to the decision 1/2016. (I. 29.) of the Constitutional Court.
} 


\section{ICL Journal @ Verlag Österreich}

follows from its earlier case-law and additionally, there was a professional consensus on the unconstitutionality of the new rules. ${ }^{34}$

The Court's argumentation about the modifications of the Postal Service Act seems trickier. At first glance it can be stated that the judges in this case were more moderate while balancing the conflicting interests and that after the previous decision it may seem as a disappointment for those rooting for the transparency of the state. But, as atlatszo.hu, a well-known Hungarian freedom of information watchdog organisation highlighted, the decision may have a different reading: according to the Court, there can be only one constitutional interpretation of the modification, namely, that under the scope of the new rules the limits of freedom of information cannot be wider than under the old rules of the Infotv. And if we accept this reading, the legal position of those, who request for public data, will not become disadvantageous, hence, the new rules do not interfere with the principle of legal certainty either. ${ }^{35}$

This interpretation offered by atlatszo.hu is a relieving one, but may seem rather trusting, if we consider two additional questions. The first one is, if the modification does not have other aim and effect than further elaborating the already existing rules of Infotv., than why does it have to be applied in current proceedings. ${ }^{36}$ The second question - and this problem was highlighted by Ágnes Czine in her dissenting opinion, as well - is that why the new provision does not contain the same condition as the Infotv., namely that denial of request for data is possible only if it does not eliminate the possibility of accessing data of public interest. These queries imply that the more likely interpretation, as judge Czine pointed out, is the one, which actually narrows freedom of information. Thus, it can only be hoped that in their practice the courts will follow the more optimistic and freedom-friendly reading of the new norms. However if not, that may open up the possibility for constitutional complaints.

Emese Szilágyi is a junior research fellow at the Hungarian Academy of Sciences, Centre for Social Sciences, Institute for Legal Studies.

Email: szilagyi.emese@tk.mta.hu

\footnotetext{
${ }^{34}$ Three watchdog organisations, the TASZ (Hungarian Civil Liberties Union), the Transparency International Hungary and the Atlatszo.hu presented their opinions to the Constitutional Court: http://public.mkab.hu/dev/dontesek.nsf/0/0e2be7972d40ca0dc1257f710051f921/\$FILE/TASZ_amicus_I_494_2 016.pdf, http://public.mkab.hu/dev/dontesek.nsf/0/0e2be7972d40ca0dc1257f710051f921/\$FILE/amicus_curiae_t_9380_t ransparency_international.002.pdf/amicus_curiae_t_9380_transparency_international.pdf; http://public.mkab.hu/dev/dontesek.nsf/0/0e2be7972d40ca0dc1257f710051f921/\$FILE/I_494_4_2016_amicus_ curiae\%20_atlatszohu.pdf; [accessed 29.5.2016].

${ }^{35}$ Az Alkotmánybíróság továbbra is a nyilvánosság pártján (The Constitutional Court remains on the side of publicity) by atlatszo.hu. https://blog.atlatszo.hu/2016/03/az-alkotmanybirosag-tovabbra-is-a-nyilvanossagpartjan/ [accessed 28.5.2016].

${ }^{36}$ The problem was highlighted by the human rights watchdog Hungarian Civil Liberties Union in its amicus curriae. http://tasz.hu/files/tasz/imce/2015/tasz_posta_amicus_20160323.pdf [accessed 1.8.2016].
} 